\title{
Onsite Wastewater System Nitrogen Loading to Groundwater in the Newport River Watershed, North Carolina
}

\author{
Charles Humphrey ${ }^{1}$, Michael A O’ Driscoll ${ }^{1} \&$ Michael C Armstrong ${ }^{1}$ \\ ${ }^{1}$ East Carolina University, United States \\ Correspondence: Charles Humphrey, East Carolina University, United States. E-mail: Humphreyc@ecu.edu
}

Received: September 17, 2012 Accepted: October 11, 2012 Online Published: October 25, 2012

doi:10.5539/enrr.v2n4p70

URL: http://dx.doi.org/10.5539/enrr.v2n4p70

\begin{abstract}
The objectives of this research were to calculate the on-site wastewater system (OWS) nitrogen loading to groundwater in the Newport River watershed, North Carolina and determine if these loads were large enough to be included in watershed nutrient management plans along with other nutrient sources such as row-crop agriculture. Nitrogen loadings were calculated using hydrological and groundwater quality data beneath 16 OWS installed in three different soil groups, and watershed demographic and soil data. Over 30,000 people use OWS in the watershed with $76 \%$ of the systems installed in group I soils (sands), $11 \%$ in group II soils (sandy loams), and $13 \%$ in group III soils (sandy clay loams). OWS in group III soils had lower total dissolved nitrogen loading rates $(0.04 \mathrm{~kg} /$ person $/ \mathrm{yr})$ to groundwater than systems in group I $(1.41 \mathrm{~kg} / \mathrm{person} / \mathrm{yr})$ and II soils $(0.33$ $\mathrm{kg} / \mathrm{person} / \mathrm{yr}$ ). The total dissolved nitrogen loading rates from OWS to groundwater, assuming 20 people/ha in group II and I soils (6.5 to $28.1 \mathrm{~kg} / \mathrm{ha} / \mathrm{yr}$ ), were significant, but less than potential agricultural contributions to groundwater $(37.5 \mathrm{~kg} / \mathrm{ha} / \mathrm{yr})$ for the area. OWS are significant sources of shallow groundwater nitrogen loading in coastal watersheds with sandy soils, and these contributions should be considered in regulatory efforts to reduce nutrient pollution.
\end{abstract}

Keywords: coastal, nitrogen, on-site wastewater, eutrophication

\section{Introduction}

\subsection{Onsite Wastewater Systems in North Carolina}

Onsite wastewater systems (OWS) are used in many rural areas where centralized sewer is not available. OWS have three basic components including a septic tank, drainfield trenches, and soil. The septic tank retains solids and allows liquid to exit the tank and enter the drainfield trenches. The drainfield trenches provide storage area for the effluent, until it (effluent) infiltrates the soil. Effluent undergoes various physical, chemical and biological treatment processes in aerated soil beneath the trenches. Approximately $60 \%$ of residences in coastal areas of North Carolina currently use individual on-site wastewater systems (OWS) for wastewater treatment and disposal (North Carolina National Estuarine Research Reserve, 2003). Much of the future growth of coastal North Carolina will likely be accommodated by OWS, meaning greater discharges of wastewater to the subsurface environment. An analysis of North Carolina Division of Environmental Health (2007) reports shows that nearly 1,500 coastal OWS fail hydraulically (surfacing effluent and/or wastewater back-up in the home) each year, temporarily contributing pollutants to surface waters and/or exposing people and animals to wastewater pollutants. OWS hydraulic failures can affect the quality of drinking water, recreational waters, shellfisheries, coastal ecology and tourism by discharging wastewater pollutants such as nutrients, bacteria and viruses directly into surface waters without any treatment by the soil. Prior research has indicated that dissolved nitrogen can be transmitted from OWS to ground and/or surface waters, resulting in the degradation of water quality (Robertson, Cherry, \& Sudicky, 1991; Harmon, Robertson, Cherry, \& Zanini, 1996; Ptacek, 1998; Corbett, Dillon, Burnett, \& Schaefer, 2002; Reay, 2004; Humphrey, O’Driscoll, \& Zarate, 2010).

\subsection{North Carolina Watershed Water Quality Issues}

The White Oak River Basin Watershed discharges into the Albemarle Pamlico Estuarine System (APES) and has had water quality problems related to excess nutrient loads. The basin has four river systems including the New River, North River, White Oak River, and Newport River. Of the estimated 47,348 ha of shellfish growing waters in the watershed, 15,032 ha or $32 \%$ are listed as impaired and over 4,320 ha of waters are nutrient sensitive 
(North Carolina Division of Water Quality, 2007). The increase in acreage of nutrient sensitive and impaired waters has corresponded with an increase in population and land use conversion from forestry and agriculture to urban landscapes. From 1982 to 1997, there was an estimated 7.7\% decline or loss of nearly 12,000 ha of forest lands, a $13.6 \%$ decline or loss of over 3,600 ha of cultivated cropland and a population increase of over 63,000 in the watershed (North Carolina Division of Water Quality, 2007). The increase in population also led to an increase in wastewater discharged to the subsurface. North Carolina Division of Environmental Health (2007) reports indicate that from 1995 to 2006, over 13,800 new septic systems were installed in counties within the Newport River Watershed. Furthermore, the counties (Carteret and Onslow) that contain most of the watershed acreage and have the largest populations are expected to see $13.9 \%-15.8 \%$ increases in population from 2000 to 2020 (North Carolina Division of Water Quality, 2007). Future growth is likely to be accommodated by an increase in the number of OWS and an increase in wastewater that is discharged to the subsurface.

\subsection{Watershed Nutrient Regulations}

North Carolina regulations were developed to enhance the quality of water. Water quality regulations targeted agricultural producers, industrial and municipal wastewater treatment plants, and developments that generate significant stormwater runoff (15A NCAC 2B $.0232-.0240$ and 15A NCAC 2B .0255-.0259). The potential nitrogen loads from OWS to water resources were not included in the mitigation and regulatory efforts, even though a high percentage of the population in the APES watershed used OWS and previous studies have shown potential for significant nitrogen contributions from OWS (Robertson, Cherry, \& Sudicky, 1991; Harmon, Robertson, Cherry, \& Zanini, 1996; Ptacek, 1998; Corbett, Dillon, Burnett, \& Schaefer, 2002; Reay, 2004; Pradhan, Hoover, Austin, \& Devine, 2007). In accordance with the nutrient sensitive waters management strategies, best management practices for agriculture such as controlled drainage, riparian buffers, and nutrient management plans must be implemented on enough farm land to reduce nitrogen loading by $30 \%$ from agriculture sources. Requirements for engineered runoff controls such as stormwater wetlands, wetponds, and bioretention cells are also mandated for new developments in urban areas to reduce stormwater and nitrogen runoff. Nitrogen loads from OWS are not accounted for in the nutrient management strategies. When agricultural lands are converted to residential or commercial developments, the agricultural industry/sector receives a nitrogen reduction credit due to the land use conversion (and loss of fertile area). While stormwater runoff (and stormwater delivered nitrogen) from newly developed properties often require engineered runoff controls, the nitrogen loads from OWS serving these developments are not addressed. However, Reay (2004) reported that nitrogen loading from septic systems to shallow groundwater in coastal Virginia, United States of America, was similar to nitrogen loadings from predominant agriculture in the region. Therefore, when land use changes from agricultural to residential/urban development, actual nitrogen loading reduction to the groundwater and eventually the estuary may not be realized.

\subsection{Significance}

As more land is converted from agriculture and forestry to residential and commercial developments, the number of OWS will increase, and so too will the nitrogen loading to ground and surface waters via OWS. This research aims to calculate the nitrogen loads contributed from OWS to shallow groundwater in the Newport River watershed (Figure 1), a coastal North Carolina watershed that has experienced excess nutrient loadings.

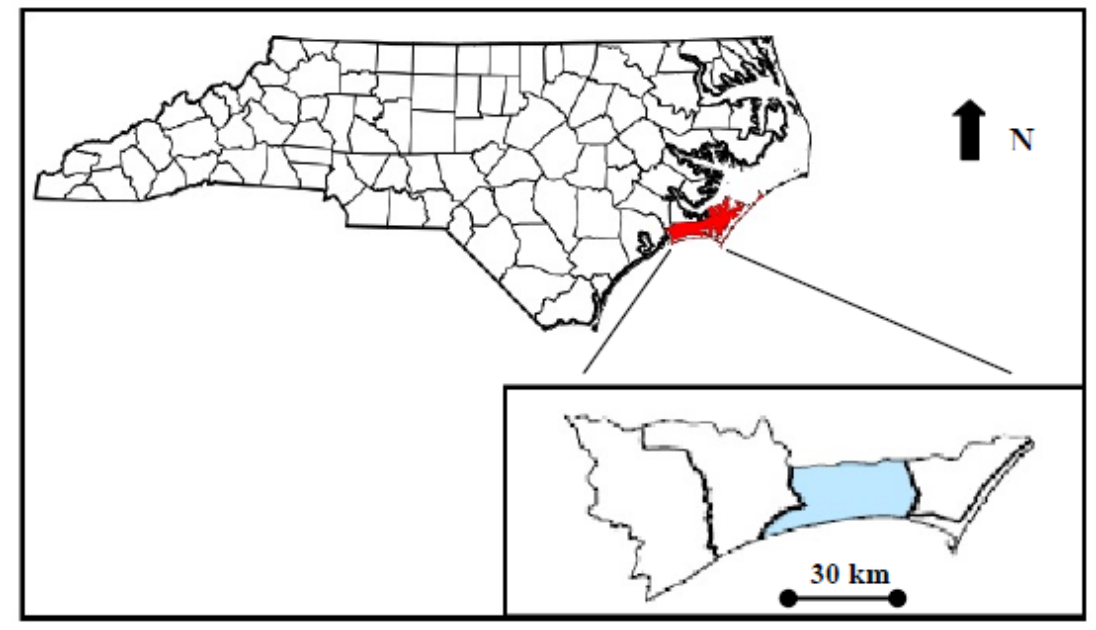

Figure 1. Newport River watershed in coastal North Carolina, United States of America 


\section{Materials and Methods}

\subsection{Onsite Wastewater Systems and Groundwater Monitoring}

Sixteen single-family dwellings with OWS and associated yards located within in the Newport River Watershed, North Carolina were selected for this study. The sites were chosen because they represented different areas of the watershed including inland areas that drain to freshwater rivers, areas on the mainland immediately adjacent to the estuary, and areas on the barrier islands. Each site was instrumented with a minimum of two wells $(10 \mathrm{~cm}$ diameter PVC) installed between and/or down-gradient from the OWS. The wells were nested at different depths and samples and environmental readings were collected and analyzed from both wells (Figure 2). At each site, the septic system components were located using permit information from the Environmental Health Department and a manual push probe. The methods, soil, and site characteristics were described in more detail in previous studies (Humphrey, O'Driscoll, \& Zarate, 2010; Humphrey \& O'Driscoll, 2011). Sites were pooled into groups based on their soil textural characteristics at the depth of the OWS dispersal field trenches (group I includes sands, group II inlcudes coarse loams, or group III includes fine loams). Dissolved inorganic nitrogen concentrations $\left(\mathrm{NH}_{4}\right.$ and $\left.\mathrm{NO}_{3}\right)$ in groundwater were also analyzed and described previously (Humphrey, O'Driscoll, \& Zarate, 2010). This study will focus on total dissolved nitrogen $\left(\mathrm{NO}_{3}^{-}-\mathrm{N}+\right.$ dissolved kjeldahl nitrogen) mass loadings from OWS to groundwater.

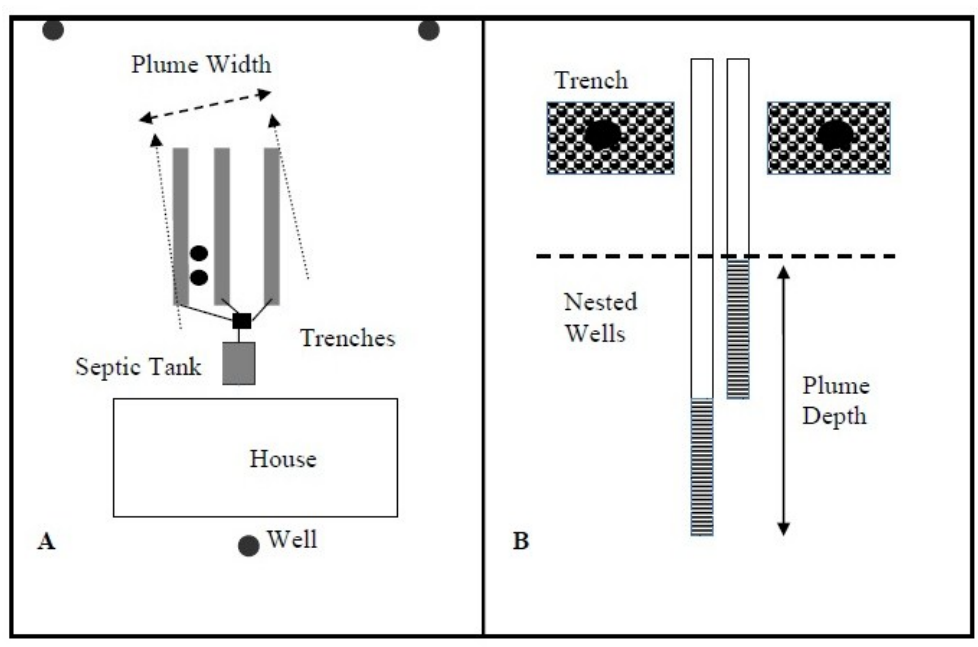

Figure 2. Plan-view (A) and cross-sectional view (B) of a groundwater monitoring design to determine the plume area width and depth

Groundwater adjacent to the OWS was analyzed for $\mathrm{NH}_{4}-\mathrm{N}$ and $\mathrm{NO}_{3}-\mathrm{N}$, monthly for 1 year and 1 month, using a YSI Sonde 6920 water quality meter. Groundwater samples were collected form the wells using disposable bailers. The wells were purged three times with the bailer to allow "new" water to enter the well, and then a sample was poured into bottles for field analysis with the meter. Septic tank effluent samples were collected by removing the access manhole and lowering a sample bottle or disposable bailer into the liquid layer of the tank. The samples bottles were filled, capped, stored in a cooler with ice, and transported to the laboratory for analysis Septic tank and groundwater samples were collected from the sites and analyzed for total dissolved nitrogen $\left(\mathrm{NO}_{3}{ }^{-} \mathrm{N}+\right.$ dissolved kjeldahl nitrogen) two to three times at the North Carolina State University Soil Science Department Analytical Services laboratory using a Quick Chem 8000 Lachet Analyzer, with procedures described in Methods for Examination of Water and Wastewater (American Public Health Association, 1998). For most tanks and groundwater, the organic fraction of nitrogen was significant, and thus the mean TDN (dissolved kjeldahl $+\mathrm{NO}_{3}{ }^{-} \mathrm{N}$ ) concentration was calculated based on the 2-3 samples sent for laboratory analysis rather than the mean DIN (organic fraction not included) concentrations determined monthly for one year and one month using the YSI Sonde. Ten of 16 septic tanks were sampled, because 6 septic tanks were not readily accessible. Three of four septic tanks in the group II and group III soils were sampled (6 total), and 4 of 8 tanks in group I soils were sampled. Average septic tank and groundwater total dissolved nitrogen (TDN) concentrations were determined for each soil group Groundwater TDN concentrations beneath OSW in sands (group I) were compared to coarse loams (group II) and fine loams (group III) to assess the influence of soil type 
on nitrogen concentration reduction from OWS. Mann Whitney non-parametric tests were performed using Minitab 16 to determine if the differences in TDN concentrations for OWS in the three soil groups were statistically significant $(\mathrm{p} \leq 0.05)$

\subsection{Onsite Wastewater System Nitrogen Loadings to Shallow Groundwater}

Groundwater discharge at each site was calculated using Darcy's law (Eq. 1):

$$
\mathrm{Q}=\mathrm{KA} * \mathrm{dh} / \mathrm{dl}
$$

where groundwater discharge $(\mathrm{Q})$, is a function of the hydraulic conductivity $(\mathrm{K})$, the plume area $(\mathrm{A})$ and the hydraulic gradient $(\mathrm{dh} / \mathrm{dl}$ ). Slug tests (Domenico \& Schwartz, 1998) were performed at each site to calculate saturated hydraulic conductivity. The monitoring wells at the 16 sites were located and plotted on maps using a Global Positioning Systems (GPS) and their relative elevations were surveyed using laser levels. The relative elevation data was coupled with the water level depth information to calculate the relative elevation of the water table at each well. With the elevation and GPS spatial data, the three-point problem method (Domenico \& Schwartz, 1998) was used to calculate groundwater flow direction and to determine the hydraulic gradient $(\mathrm{dh} / \mathrm{dl})$. OWS groundwater plume width was based on the configuration of septic system drainfield and the groundwater flow direction (Figure 2). Plume depth was based on the water level and water quality data obtained from the deep and shallow monitoring wells $(150 \mathrm{~cm}$ total screen interval) adjacent to the system (Figure 2$)$. The plume width and depth were used to calculate the cross sectional area of the plume (A). Groundwater discharge and mean groundwater TDN concentrations were used to calculate OSW nitrogen loads to groundwater for each system. The mean nitrogen load to shallow groundwater was calculated for each soil group (group I, II, and III) by pooling the TDN loading data from the individual systems installed in the soil groups. Site GI-H was the only seasonally occupied home, so the annual wastewater generated was smaller than other sites. Therefore, pooled TDN loadings for group I soils did not incorporate data from GI-H when statistical comparisons among soil groups were conducted. Mann Whitney non-parametric tests were performed using Minitab 16 to determine if the differences in TDN loadings for OWS in the three soil groups were statistically significant $(\mathrm{p} \leq 0.05)$

\subsection{Population Using Onsite Wastewater Systems in the Newport River Watershed}

For the Newport River watershed the TDN loading to shallow groundwater was estimated by multiplying the mean TDN loading rate per person for each soil group by the population using OWS in each soil group. The population within the Newport River watershed was determined using demographic information from the North Carolina Office of State Budget and Management (2009) and Carteret County Economic Development Council (2009) for the Towns and Cities of Morehead, Beaufort, Newport, Pine Knoll Shores, Indian Beach, Emerald Isle, Bogue, Atlantic Beach, Cape Carteret and Cedar Point, and the unincorporated areas. The geographic boundaries of the sewer/package plant service areas were delineated using maps and information provided by town officials (personal communication, Newport Planning Office, Carteret County Health Department, Town of Beaufort and Morehead City Town Manager, 2009) and engineering reports (Dickson, 2007). The number of people serviced by these centralized systems was subtracted from the total population of the watershed to yield the number of people using OWS within the watershed. By grouping adjacent towns using zip code population data and subtracting out the municipal populations of each using sewer services, an estimate of OWS use for the groups of towns were calculated. Soil and demographic data from Newport, Bogue, Morehead City and Beaufort were pooled into one association (MH), data for Atlantic Beach, Indian Beach, Pine Knoll Shores and Emerald Isle comprised another association (BI) and Cape Carteret and Cedar Point made the last association (CC). Once the population statistics and geographic boundaries of the sewer service areas were established, aerial photographs and web soil surveys were used to determine the location of developments using septic systems (outside sewer service areas).

\subsection{Delineation of Areas Served by Septic Systems}

Soil surveys are land use planning tools published and digitized by the United States Department of Agriculture. Soil series and soil boundaries are provided in the web soil survey as a data layer that is overlain on aerial photographs (United States Department of Agriculture, 2009). The web soil survey was used to create "areas of interest" for developments served by OWS. Areas of interest (AOI) were produced for each town (Figure 3). The boundaries of municipal areas serviced by sewer, and agricultural, forestry land uses, and sparse residential developments were excluded from the (AOI) procedure. A spreadsheet was produced with the creation of each AOI that included the acreage and percentage of each soil series within the AOI and the total area per AOI. 


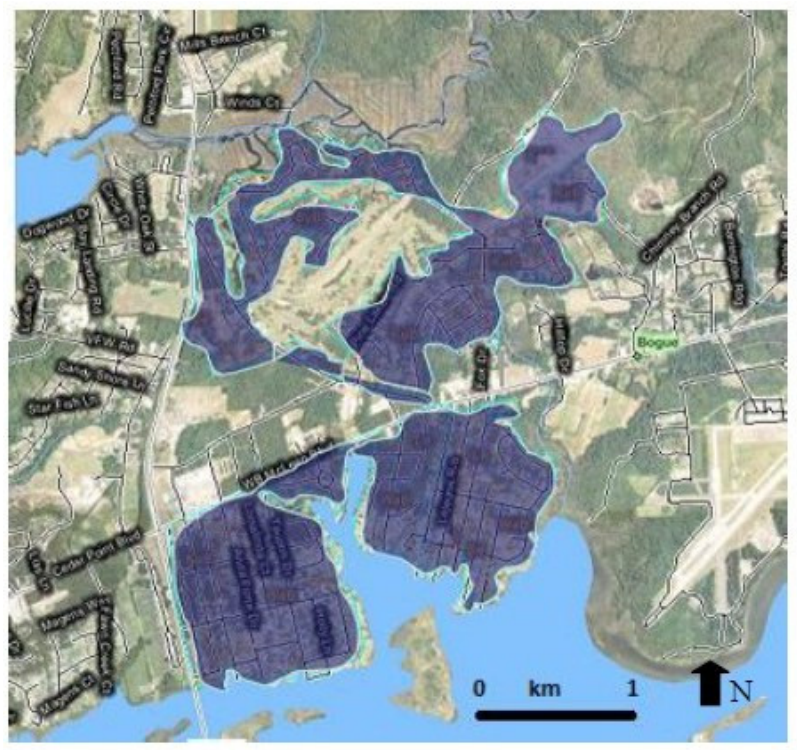

Figure 3. Web soil survey map of Cape Carteret, North Carolina, USA, including areas that were developed and use onsite wastewater treatment systems (shaded regions)

\subsection{Soil Group Determination}

Each soil series was catalogued as a group I, II, or III depending on the soil texture characteristics of the series at the 45 to $120 \mathrm{~cm}$ depth range (soil group depends on the textural group beneath the trench bottom and most systems are installed between $45-90 \mathrm{~cm}$ deep). Therefore for each town and association, the percentage of land area used for OWS with the group I, II, and III soils was determined. The total population of the town/area using OWS was then multiplied by the ratio of land with soil group I, II, and III for each area to estimate the number of people using OWS in the three soil groups. With an estimate of the population using OWS with soil groups I, II, and III and the mean nitrogen loading rate to the groundwater for each soil group, an estimate of the loading of nitrogen to the groundwater in the Newport River watershed was calculated.

\section{Results}

\subsection{Septic Tank Nitrogen Concentrations}

Mean septic tank TDN concentrations for systems in the three soil groups ranged from 83.3 to $151.8 \mathrm{mg} / \mathrm{L}$, and were similar to concentrations reported in other studies (Ptacek, 1998; Water Environment Research Federation, 2009). More specifically, septic tanks in group II soils had the highest mean TDN concentrations (151.8 \pm 43.2 $\mathrm{mg} / \mathrm{l})$ followed by tanks in group I $(108.6 \pm 35.2 \mathrm{mg} / \mathrm{L})$ and group III $(83.3 \pm 42.2 \mathrm{mg} / \mathrm{L})$ soils. The differences between the mean septic tank TDN concentrations were not statistically significant $(\mathrm{p}>0.05)$.

\subsection{Groundwater Nitrogen Loading}

OWS with group I soils had the highest mean groundwater TDN concentrations $(39.5 \mathrm{mg} / \mathrm{L})$, hydraulic gradients (0.018), and hydraulic conductivities ( $3.34 \mathrm{~m} /$ day), thus resulting in the highest TDN loading rates of the soil groups (1.41 kg/person/yr) (Table 1). OWS with group II soils had similar (to group I) mean TDN concentrations $(36 \mathrm{mg} / \mathrm{L})$, but the average hydraulic conductivity was an order of magnitude smaller $(0.33 \mathrm{~m} / \mathrm{day})$, and the hydraulic gradient (0.013) was also smaller, leading to lower TDN loading rates $(6.5 \mathrm{~kg} / \mathrm{person} /$ day) (Table 1$)$. While groundwater TDN concentrations were not significantly different beneath OWS with group I and II soils, the TDN loading rates were significantly higher $(\mathrm{p}=0.01)$ beneath OWS with group I, due to larger hydraulic conductivity and hydraulic gradient values that OWS with group II soils. OWS with group III soils had the largest mean plume area $\left(27.9 \mathrm{~m}^{2}\right)$, but lowest mean TDN concentrations $(4.5 \mathrm{mg} / \mathrm{L})$, smallest mean hydraulic gradient (0.009) and lowest mean hydraulic conductivity $(0.019 \mathrm{~m} /$ day), resulting in the lowest TDN loading rates $(0.08 \mathrm{~kg} / \mathrm{person} / \mathrm{yr})$ (Table 1$)$. Groundwater TDN concentrations were significantly lower $(\mathrm{p}<0.05)$ beneath OWS in group III soils relative to group I and II soils. The groundwater TDN loading rates were significantly higher $(\mathrm{p}=0.01)$ for OWS in group I soils and II soils in comparison to group III. Group III sandy clay loam soils had the highest effective cation exchange capacity (mean: $7.4 \pm 0.3 \mathrm{cmol} / \mathrm{kg}$ ), followed by group I sands $(3.1 \pm 1.8 \mathrm{cmol} / \mathrm{kg})$ and group II sandy loams $(2.9 \pm 0.6 \mathrm{cmol} / \mathrm{kg})$ (Table 1$)$. 
Table 1. Groundwater total dissolved nitrogen (TDN) loading parameters and estimates for systems in group I soils (GI), group II soils (GII), and group III soils (GIII) in various locations within the Newport River Watershed. $\left(^{*}\right)$ indicates a seasonally used home, thus mean and standard deviations are calculated with and without this site. Effective cation exchange capacity (ECEC) is also reported

\begin{tabular}{|c|c|c|c|c|c|c|c|c|c|c|}
\hline System & $\begin{array}{l}\text { Watershed } \\
\text { Location }\end{array}$ & $\begin{array}{c}\text { TDN } \\
(\mathrm{mg} / \mathrm{L})\end{array}$ & $\begin{array}{c}\text { ECEC } \\
(\mathrm{cmol} / \mathrm{kg})\end{array}$ & $\mathrm{DH} / \mathrm{DL}$ & $\begin{array}{c}\mathrm{K} \\
\text { (m/day) }\end{array}$ & $\begin{array}{l}\text { Plume } \\
\text { Area } \\
(\mathrm{m} 2)\end{array}$ & $\begin{array}{c}\text { TDN } \\
\text { Loading } \\
\mathrm{Kg} / \mathrm{yr}\end{array}$ & Persons & $\begin{array}{l}\text { TDN Loading } \\
\mathrm{Kg} / \text { person/yr }\end{array}$ & $\begin{array}{c}\text { TDN } 20 \\
\text { persons/ha } \\
\mathrm{Kg} / \mathrm{ha} / \mathrm{yr}\end{array}$ \\
\hline GI-A & Riverine & 32.3 & 5.6 & 0.027 & 0.98 & 9.3 & 2.9 & 2 & 1.45 & 29.01 \\
\hline GI-B & Riverine & 82.3 & 1.2 & 0.027 & 2.47 & 5.6 & 11.22 & 4 & 2.8 & 56.09 \\
\hline GI-C & Riverine & 22.2 & 3.2 & 0.035 & 1.01 & 8.4 & 2.41 & 2 & 1.2 & 24.06 \\
\hline GI-D & Barrier Island & 24.7 & 2.3 & 0.012 & 1.95 & 20.4 & 4.3 & 3 & 1.43 & 28.69 \\
\hline GI-E & Barrier Island & 48.1 & 1.5 & 0.004 & 8.44 & 3.7 & 2.19 & 2 & 1.1 & 21.93 \\
\hline GI-F & Barrier Island & 24.5 & 2 & 0.034 & 1.37 & 5.6 & 2.33 & 2 & 1.17 & 23.33 \\
\hline GI-G & Barrier Island & 42.1 & 5.6 & 0.002 & 5.7 & 7.8 & 1.37 & 2 & 0.69 & 13.8 \\
\hline GI-H* & Barrier Island & 14.7 & 3.1 & 0.002 & 4.82 & 7.4 & 0.38 & 2 & 0.19 & 3.83 \\
\hline Avg & & $36.4 / 39.5$ & $3.1 / 3.1$ & $0.018 / 0.020$ & $3.13 / 3.34$ & $8.5 / 8.7$ & $3.62 / 3.82$ & $2.4 / 2.4$ & $1.25 / 1.41$ & $25.1 / 28.1$ \\
\hline STDEV & & $21.5 / 21.2$ & $1.7 / 1.8$ & $0.014 / 0.014$ & $2.71 / 2.85$ & $5.1 / 5.51$ & $3.36 / 3.38$ & $0.7 / 0.8$ & $0.75 / 0.66$ & $15.04 / 13.33$ \\
\hline GII-A & Riverine & 29.4 & 3.2 & 0.017 & 0.37 & 19 & 1.28 & 4 & 0.32 & 6.41 \\
\hline GII-B & Riverine & 19.6 & 3.5 & 0.017 & 0.37 & 19 & 0.85 & 4 & 0.21 & 4.27 \\
\hline GII-C & Riverine & 70.4 & 2.8 & 0.008 & 0.3 & 25.2 & 1.55 & 3 & 0.52 & 10.36 \\
\hline GII-D & Riverine & 24.5 & 2.1 & 0.008 & 0.3 & 23.2 & 0.5 & 2 & 0.25 & 5 \\
\hline Avg & & 36 & 2.9 & 0.013 & 0.34 & 21.6 & 1.05 & 3.3 & 0.33 & 6.51 \\
\hline STDEV & & 23.3 & 0.6 & 0.005 & 0.04 & 3.1 & 0.46 & 1 & 0.14 & 2.71 \\
\hline GIII-A & Estuarine & 3.8 & 7 & 0.006 & 0.15 & 27.9 & 0.03 & 2 & 0.02 & 0.35 \\
\hline GIII-B & Estuarine & 3.3 & 7.7 & 0.006 & 0.18 & 40.9 & 0.05 & 2 & 0.03 & 0.53 \\
\hline GIII-C & Estuarine & 5.3 & 7.2 & 0.007 & 0.09 & 23.2 & 0.03 & 2 & 0.01 & 0.28 \\
\hline GIII-D & Estuarine & 5.6 & 7.5 & 0.015 & 0.34 & 19.5 & 0.2 & 2 & 0.1 & 2.03 \\
\hline Avg & & 4.5 & 7.4 & 0.009 & 0.19 & 27.9 & 0.08 & 2 & 0.04 & 0.8 \\
\hline STDEV & & 1.1 & 0.3 & 0.004 & 0.11 & 9.3 & 0.09 & 0 & 0.04 & 0.89 \\
\hline
\end{tabular}

\subsection{Demographic and Soil Group Data for the Newport Watershed}

The MH association contained most of the watershed's OWS served population (22,169 of 30,277 people) and the dominant soil group was group I (61.8\%) followed by group III (20.5\%) and group II (17.7\%) (Table 2). For the BI association the total estimated population using OWS was 6,958 , with $100 \%$ of the systems installed in group I soils (Table 3). The CC association had 1,150 people with $97.1 \%$ of the population using OWS with group I soils, $2.4 \%$ with group II soils and $0.5 \%$ with group III soils (Table 4 ). The annual TDN loading to groundwater was an estimated $32,188 \mathrm{~kg}$ (Table 5). For the entire watershed $72 \%$ of the sites served by OWS were with group I soils, $13 \%$ were group II soils, and $15 \%$ were group III soils (Table 5 ). Therefore, $85 \%$ of the watershed was coarse-textured, sandy soils. Over $95 \%$ of the OWS groundwater nitrogen loading was from systems with group I soils (Table 5).

The specific soil series for the sites included Mandarin, Baymeade, Newhan and Fripp for the group I soils, Goldsboro for the group II soils, and Altavista for the group III soils. These soils comprise a total of 1561 ha, or $26 \%$ of the developed study area that is served by OWS. Thus, the research sites were representative of the watershed soils.

\section{Discussion}

Research has shown that OWS installed in soils with higher percentages of silt and clay are more efficient at reducing wastewater pollutant concentrations due to higher cation exchange capacities, more reactive surface area, longer residence times, and more potential for denitrification (Karathanasis, Mueller, Boone, \& Thompson, 2006; Humphrey, O’Driscoll, \& Zarate, 2010). The group III soils in this study had the largest mean effective 
cation exchange capacity (group III-7.4 \pm 0.3 , group II- $2.9 \pm 0.6$, and group I-3.1 $\pm 1.8 \mathrm{cmol} / \mathrm{kg}$ ), lowest mean hydraulic conductivity (group III: $0.19 \pm 0.11$, group II: $0.34 \pm 0.4$, and group I: $3.34 \pm 2.85 \mathrm{~m} /$ day), and lowest TDN loading rates (group III: $0.04 \pm 0.04$, group II: $0.33 \pm 0.14$, and group III: $1.41 \pm 0.66$ ) of the soil groups, thus supporting the conclusions of previous research. The OWS with group I soils (sands) had the highest TDN loading rates, and OWS with group II were intermediate. These data suggest that watersheds with predominately coarse-textured, sandy soils that are served by OWS may have significantly higher groundwater nitrogen concentrations than watersheds dominated by more clay-rich soils. In North Carolina, the sand content of soil typically increases as you travel from west to east (Daniels, Buol, Kleiss, \& Ditzler, 1999) with some of the barrier islands having essentially $100 \%$ of the buildable land in soil group I ( $>88 \%$ sand fraction) (Table 3 ). Piedmont and Mountain soils typically have relatively higher percentages of silt and clay (group III and IV soils) and therefore are less likely to experience elevated nitrogen loadings from OWS to the groundwater. The data from this research supports the findings of other studies by showing that OWS installed in soils with higher reactive surface areas and lower hydraulic conductivities provide better reduction of OWS pollutants such as nitrogen. However, more field based research should be conducted to confirm the transport of OWS derived nitrogen to groundwater and adjacent surface waters in different soil series, landscape positions and with different actual wastewater loading rates.

Table 2. (MH) soils data from Morehead City, Newport, Bogue and Beaufort

\begin{tabular}{lll}
\hline MH Association Soil Series & Total (ha) & Soil Group \\
\hline Autryville Loamy Fine Sand, 0-6\% slopes (AuB) & 162.5 & II \\
Altavista Loamy Fine Sand, 0-2\% slopes (AaA) & 134.8 & III \\
Augusta Loamy Fine Sand (Ag) & 119.7 & III \\
Arapahoe Fine Sandy Loam (Ap) & 179.4 & II \\
Baymeade Fine Sand, 1-6\% slopes (ByB) & 160.4 & I \\
Carteret Sand, freq. flooded (CH) & 13.4 & I \\
Conetoe Loamy Fine Sand, 0-5\% slopes (CnB) & 39.7 & I \\
Corolla_Urban Land Complex (Cu) & 3.9 & III \\
Deloss Fine Sandy Loam (De) & 16.5 & III \\
Goldsboro Loamy Fine Sand, 0-2\% slopes (GoA) & 102.6 & II \\
Hobucken Mucky Fine Sandy Loam, freq. flooded (HB) & 4 & II \\
Kureb Sand, 0-6\% slopes (KuB) & 598.3 & I \\
Leon Sand (Ln) & 741.1 & I \\
Lynchburg Fine Sandy Loam (Ly) & 69.7 & III \\
Masontown Mucky Loam, freq. flooded (MA) & 37.7 & II \\
Mandarin Sand (Mn) & 43 & I \\
Murville Mucky Sand (Mu) & 257.6 & I \\
Norfolk Loamy Fine Sand, 0-2\% slopes (NoA) & 34 & III \\
Onslow Loamy Sand (On) & 82.2 & I \\
Pantego Fine Sandy Loam (Pa) & 33.7 & III \\
Rains Fine Sandy Loam (Ra) & 148.2 & III \\
Seabrook Fine Sand (Se) & 197.4 & I \\
State Loamy Fine Sand, 0-2\% slopes (StA) & 9.6 & II \\
Tomotley Fine Sandy Loam (Tm) & 106.5 & III \\
Torhunta Mucky Fine Sandy Loam (To) & 132.2 & II \\
Wando Fine Sand, 0-6\% slopes (WaB) & 357.5 & I \\
Total & 3785.6 & \\
\hline
\end{tabular}


Table 3. Barrier Island (BI) soils data from Pine Knoll Shores, Atlantic Beach, Emerald Isle, and Indian Beach

\begin{tabular}{lll}
\hline BI Association Soil Series & Total (ha) & Soil Group \\
\hline Corolla Fine Sand (Co) & 78.5 & I \\
Fripp Fine Sand, 2-30\% slopes (Fr) & 255.8 & I \\
Newhan-Corolla (Nc) & 503.5 & I \\
Duckston Fine Sand, freq. flooded (Du) & 54.1 & I \\
Newhan-(Ne) & 85.2 & I \\
Newhan Fine Sand, (Nh) & 298.4 & I \\
Corolla-Urban Land Complex (Cu) & 52 & I \\
Carteret Sand, low, freq. flooded (CL) & 3.5 & I \\
Total & 1331 & \\
\hline
\end{tabular}

Table 4. (CC) association soils data from Cedar Point and Cape Carteret

\begin{tabular}{lcc}
\hline \multicolumn{1}{c}{ CC Association Soil Series } & Area (ha) & Group \\
\hline Arapahoe Fine Sandy Loam (Ap) & 16.5 & II \\
Baymeade Fine Sand, 1-6\% slopes (ByB) & 111.6 & I \\
Carteret Sand, freq. flooded (CH) & 0.5 & I \\
Corolla-Urban Land Complex (Cu) & 8.4 & I \\
Hobucken Mucky Fine Sandy Loam, freq. flooded (HB) & 2.9 & II \\
Kureb Sand, 0-6\% slopes (KuB) & 154.8 & I \\
Leon Sand (Ln) & 57.8 & I \\
Newhan Fine Sand, dredged, 2-30\% slopes (Nd) & 0.8 & I \\
Norfolk Loamy Fine Sand, 2-6\% slopes (NoB) & 3.2 & I \\
Seabrook Fine Sand (Se) & 69 & I \\
Wando Fine Sand, 0-6\% slopes (WaB) & 301.6 & I \\
Total & 727.1 & \\
\hline
\end{tabular}

Table 5. Onsite wastewater systems total dissolved nitrogen loading to groundwater for the Morehead City Association (MH), Barrier Islands (BI), and Cape Carteret and Cedar Point Associations (CC)

\begin{tabular}{ccccccccc}
\hline & \multicolumn{4}{c}{ Population } & \multicolumn{5}{c}{ TDN Loading (kg/yr) } \\
\hline Association & OWS & Group I & Group II & Group III & Group I & Group II & Group III & Total \\
MH & 22169 & 13700 & 3924 & 4544 & 19317 & 1295 & 182 & 20794 \\
BI & 6958 & 6958 & 0 & 0 & 9811 & 0 & 0 & 9811 \\
CC & 1150 & 1116 & 29 & 6 & 1574 & 9 & 0 & 1583 \\
Total & 30277 & 21774 & 3953 & 4550 & 30702 & 1304 & 182 & 32188 \\
\hline
\end{tabular}

Nitrogen contributions to ground and surface waters from OWS are not considered in watershed-scale nutrient management strategies in North Carolina. Regulatory emphasis for non-point sources of pollution has focused on agriculture and stormwater runoff, with growing concern that atmospheric deposition (Whitall, Hendrickson, \& Paerl, 2003) can be significant as well. This research has indicated that for developments with five homes and 20 people per ha $(0.2$ ha lots), the average TDN loadings rates for OWS with sandy soils would be $28.1 \mathrm{~kg} / \mathrm{ha}$. Furthermore, Carteret County is a tourist attraction and while the year-round population of the County is just over 63,000 (North Carolina Office of State Budget and Management, 2008), the summer the population can more than double as people visit the beach communities (Carteret County Economic Development, 2008). Therefore, it is possible that wastewater nitrogen loads processed by OWS and entering groundwater also more than double during the tourism months, thus increasing the groundwater TDN loading to more than an average of 
$28.1 \mathrm{~kg} / \mathrm{ha}$ for OWS with sandy soils. Groundwater TDN loading in sandy areas with high densities of OWS is comparable to TDN loading to groundwater from cropland $(37.5 \mathrm{~kg} / \mathrm{ha})$ in the same region (Neuse Basin Oversight Committee, 2009).

The nitrogen accounting tool used in North Carolina would indicate a 100\% nitrogen loading reduction credit when agricultural fields were converted to residential development. There is no mechanism in the accounting tool to include the nitrogen contributions $(28.1 \mathrm{~kg} / \mathrm{ha})$ from OWS to groundwater. This oversight may lead to an underestimation of the actual nitrogen loads generated from the residential development (and OWS) by $75 \%$. The overall contributions from OWS will increase as urbanization occurs, and these loadings should be included in nutrient management strategies for the watersheds.

\section{Conclusions}

There was an order of magnitude difference in nitrogen loading when comparing systems with group I and II (sand and sandy loam soils) to the finer textured group III (clay loam and clay) soils. Watersheds with greater percentages of clay soils should have lower risks for shallow groundwater $\mathrm{N}$ contamination, but more field based research is needed for confirmation. Currently OWS in North Carolina are designed based on the hydraulic conductivity of the soil, with sandy soils assigned higher wastewater application loading rates, resulting in smaller drainfield areas (15A NCAC 18A .1955 b). This methodology allows for relatively high density development with the soil groups (I and II) that are the least effective at reducing nitrogen loading to groundwater. Also, many of the sandier soils are adjacent to estuaries and rivers that have experienced problems with excess nutrient loadings and eutrophication.

The potential nitrogen loading from OWS to surface waters should be accounted for in future water quality improvement initiatives and regulations. If OWS contributions are not taken into account then the expectations for water quality improvement may not be met. It should also be noted that human wastewater treatment via centralized sewer and package plants can also contribute significant nitrogen loads to surface and groundwater waters. More work is also needed in comparing the nitrogen loads and overall environmental impacts from different wastewater treatment systems and methods and in different geological settings.

\section{References}

American Public Health Association/American Water Works Association/Water Environment Federation. (1998). Standard Methods for the Examination of Water and Wastewater (20th ed.). Baltimore, MD: United Book Press.

Carteret County Economic Development Commission. (2008). Demographics. Retrieved December 2009, from http://www.carteretedc.com/demographics/population.php

Corbett, D. R., Dillon, K., Burnett, W., \& Schaefer, G. (2002). The spatial variability of nitrogen and phosphorus concentration in a sand aquifer influenced by onsite sewage treatment and disposal systems: a case study on St. George Island, Florida. Environmental Pollution, 117(2) 337-345.

Daniels, R. B., Buol, S. W., Kleiss, H. J., \& Ditzler, C. A. (1999). Soil Systems in North Carolina. Technical Bulletin 314. North Carolina State University, Soil Science Department, Raleigh, NC.

Domenico, P. A., \& Schwartz, W. (1998). Physical and Chemical Hydrogeology (2nd ed.). New York: John Wiley \& Sons, Inc.

Dickson, W. K. (2007). Town of Atlantic Beach Wastewater Master Planning Study. Preliminary Engineering Report.

Harmon, J., Robertson, W. D., Cherry, J. A., \& Zanini, L. (1996). Impacts on a sand aquifer from an old septic system: Nitrate and Phosphate. Ground Water, 34(6), 1105-1114.

Humphrey, C. P., \& O'Driscoll, M. A. (2011). Biogeochemistry of Groundwater Beneath On-site Wastewater Systems in a Coastal Watershed. Universal Journal of Environmental Research and Technology, 1(3), 320-328.

Humphrey, C. P., O'Driscoll, M. A., \& Zarate, M. A. (2010). Controls on Groundwater Nitrogen Contributions from On-site Wastewater Systems in Coastal North Carolina. Journal of Water Science and Technology, 62(6), 1448-1455.

Humphrey, C. P., O'Driscoll, M. A., \& Zarate, M. A. (2011). Evaluation of On-site Wastewater System E. coli Contributions to Shallow Groundwater in Coastal North Carolina. Journal of Water Science and Technology, 63(4), 789-795. 
Karathanasis, A. D., Mueller, T. G., Boone, B., \& Thompson, Y. L. (2006). Nutrient removal from septic effluents as affected by soil thickness and texture. Journal of Water Health, 4(2), 177-195.

Neuse Basin Oversight Committee. (2009). Annual Progress Report on the Neuse Agricultural Rule (15A NCAC $2 B$.0238). Report to the Environmental Management Commission. Raleigh, NC.

North Carolina Department of Environment and Natural Resources. (2003). Nutrient Sensitive Waters Management Strategy. Retrieved December 2009, from http://h2o.enr.state.nc.us/nps/neuse.htm

North Carolina Division of Environmental Health: On-site Wastewater Section. (2007). County on-site activity reports. Retrieved January, 2010, from http://www.deh.enr.state.nc.us/osww_new//progimprovteam.htm

North Carolina Division of Water Quality Basinwide Planning Program. (2007). White Oak River Basinwide Water Quality Plan. Retrieved January, 2010, from http://portal.ncdenr.org/web/wq/ps/bpu/basin/whiteoak/2007

North Carolina National Estuarine Research Reserve. (2003). Workshop Proceedings. "Addressing Microbial Pollution in Coastal Waters". Duke University Marine Laboratory, Beaufort, NC.

North Carolina Office of State Budget and Management. (2009). Carteret County Demographic Data. Retrieved September, 2009, from http://www.osbm.state.nc.us/

Pradhan, S. S., Hoover, M. T., Austin, R. E., \& Devine, H. A. (2007). Potential Nitrogen Contributions from On-site Wastewater Treatment Systems to North Carolina's River Basins and Sub-basins. North Carolina Agricultural Research Service Technical Bulletin 324. Raleigh, North Carolina.

Ptacek, C. J. (1998). Geochemistry of a septic system plume in a coastal barrier bar, Point Pelee, Ontario, Canada. Contaminant Hydrology, 33, 293-312.

Reay, W. G. (2004). Septic Tank Impacts on Ground Water Quality and Nearshore Sediment Nutrient Flux. Ground Water, 4(7), 1079-1089.

Robertson, W. D., Cherry, J. A., \& Sudicky, E. A. (1991). Groundwater Contamination From 2 Small Septic Systems on Sand Aquifers. Ground Water, 29(1), 82-92.

United States Department of Agriculture. (2009). Web soil survey. Reteieved December, 2009, from http://websoilsurvey.nrcs.usda.gov/app/

Water Environment Research Foundation. (2009). Influent Characterstics of the Modern Waste Stream from Single Sources. Final Report 04-Dec-01. 635 Slaters Lane, Suite 300, Alexandria, VA 22314-1177.

Whitall, D., Hendrickson, B., \& Paerl, H. (2003). Importance of atmospherically derived nitrogen to the annual nitrogen budget of the Neuse River estuary, North Carolina. Environment International, 29, 393-399. 